\title{
Different biological effect of estrogen receptor-related receptor $\alpha$ in estrogen receptor-positive and -negative endometrial carcinoma
}

\author{
MIN GAO $^{1,2}$, PENG-MING SUN $^{1}$, JIAN-LIU WANG $^{1}$, XIAO-PING LI $^{1}, \mathrm{CHAO} \mathrm{ZHAO}^{1}$ and LI-HUI WEI ${ }^{1}$ \\ ${ }^{1}$ Department of Obstetrics and Gynecology, Peking University People's Hospital, Xizhimen South Street 11, \\ 100044 Beijing; ${ }^{2}$ Department of Gynecology, Peking University School of Oncology, Beijing \\ Cancer Hospital and Institute, Fucheng Road \#52, 100036 Beijing, P.R. China
}

Received June 17, 2008; Accepted September 15, 2008

DOI: $10.3892 / \mathrm{mmr} 00000050$

\begin{abstract}
Estrogen receptor-related receptor $\alpha(E R R \alpha)$ has been identified as a nuclear transfactor closely related to estrogen receptor $\alpha(\mathrm{ER} \alpha)$. ERR $\alpha$ interferes with ER-mediated signaling pathways through competition with ER $\alpha$ for the common DNA sites and coregulators. Thus, it may participate in the tumorigenesis of estrogen-related cancers. To elucidate the roles of ERR $\alpha$ in endometrial carcinogenesis and the crosstalk between ER $\alpha$ and ERR $\alpha$, endometrial carcinoma Ishikawa and HEC-IA cells were treated with different concentrations of $17 ß-\mathrm{E}_{2}$ and/or the pure anti-estrogen drug ICI182,780. Using semi-quantitative RT-PCR and Western blot analysis, we found that $17 ß-E_{2}$ down-regulated the expression of ERR $\alpha$ in ER-positive Ishikawa cells, while up-regulating the expression of ERR $\alpha$ in ER-negative HEC-IA cells. Down-regulation in Ishikawa cells was furthermore found to be largely abrogated by ICI182,780. Additionally, we constructed endometrial carcinoma cell lines with overexpression of ERR $\alpha$ by stable transfection, renaming these Ishikawa/ERR $\alpha$ and HEC-IA/ $E R R \alpha$, respectively. To investigate the effect of ERR $\alpha$ overexpression on the biological behavior of the cells, MTT assay and flow cytometry analysis were performed in the constructed cell lines. In ER-positive Ishikawa cells, the overexpression of ERR $\alpha$ inhibited cell growth in the presence of $17 \beta-E_{2}$, an inhibitory effect that might be due to a $\mathrm{G}_{0}-\mathrm{G}_{1}$ cell cycle arrest. In contrast, overexpression of ERR $\alpha$ stimulated cell proliferation in ER-negative HEC-IA cells independently of $17 ß-\mathrm{E}_{2}$. This accelerated action was associated with changes in cell cycle distribution. Our study demonstrates that, in addition to $\mathrm{ER}, \mathrm{ERR} \alpha$ seems to be an important regulator in endometrial
\end{abstract}

Correspondence to: Dr Min Gao, Department of Obstetrics and Gynecology, Peking University People's Hospital, Xizhimen South Street 11, 100044 Beijing, P.R. China

E-mail: gaomin202@hotmail.com

Key words: estrogen receptor-related receptor $\alpha$, estrogen receptor $\alpha$, endometrial carcinoma, interaction carcinogenesis, playing different roles in estrogen-dependent and -independent endometrial carcinomas. ERR $\alpha$ might modulate the ER-mediated pathways via interference with ER $\alpha$ transcription in endometrial carcinoma cells.

\section{Introduction}

Estrogen plays a predominant role not only in the development and physiological function of female reproductive organs, but also in the proliferation and malignancy of estrogen-dependent tumors, such as breast cancer and endometrial carcinoma (1-3). Two classic nuclear receptors, human ER $\alpha$ and ERß, mediate the actions of estrogen on growth, development and physiological function in different human tissues and organs (4-6). Acting as either homodimers or heterodimers, they modulate the transcription of target genes by binding to short DNA sequences referred to as estrogen responsive elements (EREs) within the promoters $(4,7,8)$. The estrogen-ER complexes recruit coregulators to exert transcriptional activity in a liganddependent manner. By screening the cDNA library with the DNA binding domain (DBD) of ER $\alpha$ as a probe, a novel nuclear transcription factor subfamily was identified and named estrogen receptor-related receptor (ERR). The ERR subfamily, which includes the subtypes ERR $\alpha, E R R ß$ and ERR $\gamma$, displays a significant homology with $\mathrm{ER} \alpha$ at the DBD (68\% similarity of amino acids) $(9,10)$. Despite being closely related to $\operatorname{ER} \alpha$, ERRs are not activated by any known natural estrogens or physiological ligands, and are therefore classified as orphan nuclear receptors (9-12).

Similarly to ER $\alpha, E R R \alpha$ can bind to the classical EREs, which are composed of two AGGTCA motifs arranged in a palindrome structure. Moreover, ERR $\alpha$ preferentially recognizes the consensus extended half-site TnAAGGTCA, referred to as ERR responsive element (ERRE) (13-15). This type of binding site is also recognized by steroidogenic factor-1, a regulator of the steroid biosynthesis pathway. ERR family members may therefore have extensive crosstalk with other nuclear receptors through common binding sites. As we know, $\mathrm{ERR} \alpha$ may compete with ER $\alpha$ but not ERß to bind to the same binding sites and share the same coregulatory proteins, reinforcing the notion that the two subtypes of related receptors share the same target genes (16-21). However, in contrast to 
the ligand-dependent transcriptional manner of ER $\alpha, E R R \alpha$ can constitutively activate the transcription of target genes containing EREs in the absence of exogenous ligands $(16,17,19)$. Previously, ERR $\alpha$ was identified as a regulator of the human medium chain acyl coenzyme A dehydrogenase, human lactoferrin and aromatase genes $(14,15,22)$. These observations offer the additional layer of regulatory complexity for ERR $\alpha$ to modulate the estrogen-ER-target networking signal pathway.

Recent studies have reported that ERR $\alpha$ is associated with hormone-related cancers, such as breast cancer, endometrial carcinoma, ovarian cancer, prostate cancer and colorectal cancer (23-28). Our previous study also found that ERR $\alpha$ may participate in the tumorigenesis of endometrial carcinoma, and that it plays different roles according to ER $\alpha$ status (29). In this study, we explored whether ERR $\alpha$ is involved in the classical ER-mediated pathways, and investigated the function of ERR $\alpha$ in endometrial carcinogenesis. We demonstrated the different estrogenic responses of ERR $\alpha$ in ER-positive versus ERnegative endometrial carcinoma cells. Furthermore, we constructed cell lines with ERR $\alpha$ overexpression by stable transfection and examined the effects of ERR $\alpha$ overexpression on cellular proliferation and cell cycle distribution.

\section{Materials and methods}

Reagents. Water-soluble 17ß-estradiol $\left(17 \beta-\mathrm{E}_{2}\right)$ was obtained from Sigma Chemical Co. (St. Louis, MO, USA). Pure antiestrogen drug ICI182,780 was purchased from Tocris, UK. G418 was purchased from Amresco Co. (USA).

Plasmids and plasmid construction. All recombinant DNA and plasmid construction experiments were performed according to standard procedures. The sequences and orientation of the DNA fragments inserted in the plasmid constructs were verified by standard DNA sequencing. Plasmid pSG-ERR $\alpha$ and $\mathrm{pSG}-\mathrm{ER} \alpha$ containing full-length cDNA fragments were generous gifts from Professor J.M. Vanacker (LBMC, Lyon, France). Eukaryotic expression vector PLXSN-ERR $\alpha$, which contained a neomycin-resistant gene, was constructed as follows: the pSG-ERR $\alpha$ plasmid and PLXSN vector were digested with BamHI and EcoRI double-restricted endonuclease system (Promega, Mannheim, Germany); the full-length ERR $\alpha$ cDNA fragment was purified and directionally inserted into the appropriate sites in the eukaryotic expression vector PLXSN; the vectors were purified using the Wizard purification system (Promega).

Cell culture and drug treatment. Human ER-positive endometrial carcinoma Ishikawa and ER-negative endometrial carcinoma HEC-IA cells were obtained from American Type Culture Collection Center (ATCC) and cultured respectively in $90 \%$ RPMI-1640 medium or 90\% DMEM (Invitrogen) supplemented with $10 \%$ fetal bovine serum (FBS) at $37^{\circ} \mathrm{C}$ in a $5 \% \mathrm{CO}_{2}$ incubator. To determine whether $17 ß-\mathrm{E}_{2}$ regulates ERR $\alpha$ expression at the mRNA and protein levels, a drug treatment assay was performed in Ishikawa and HEC-IA cells. Before treatment with the drug, cells were transferred into phenol red-free medium containing $1 \%$ serum replacement-2 (steroid-free and growth factor-free) for additional culturing for at least $24 \mathrm{~h}$. Cells were then treated with different concentrations of $17 ß-\mathrm{E}_{2}$ (vehicle, $10^{-10}, 10^{-8}, 10^{-6} \mathrm{M}$ ) or $173-\mathrm{E}_{2}$ $\left(10^{-8} \mathrm{M}\right)$ plus pure anti-estrogen drug ICI182,780 $\left(10^{-6} \mathrm{M}\right)$ for 24 and $48 \mathrm{~h}$, and were finally harvested for semi-quantitative RT-PCR and Western blot analysis.

Stable transfection. Ishikawa and HEC-IA cells were cultured in complete culture medium to achieve $\sim 90 \%$ confluence. According to the manufacturer's instructions, transfection experiments in Ishikawa and HEC-IA cells were performed with Lipofectamine 2000 reagent (Invitrogen). PLXSN-ERR $\alpha$ vector $(1 \mu \mathrm{g})$ or PLXSN basic vector $(1 \mu \mathrm{g})$ was transfected into the Ishikawa and HEC-IA cells, respectively. After transfection for $48 \mathrm{~h}$, the culture medium was replaced by fresh selective culture medium containing G418 (800 $\mu \mathrm{g} / \mathrm{ml}$ in Ishikawa cells and $1 \mathrm{mg} / \mathrm{ml}$ in HEC-IA cells). Drug selection was sustained for 2 weeks, with selective culture medium containing G418 being changed every 3 days. Resistant clones were isolated and expanded in complete culture medium containing $300 \mu \mathrm{g} / \mathrm{ml} \mathrm{G} 418$. Several G418-resistant stable clones were screened for the analysis of ERR $\alpha$ expression by semi-quantitative RT-PCR and Western blotting. The selected clones with ERR $\alpha$ overexpression were renamed Ishikawa/ ERR $\alpha$ and HEC-IA/ERR $\alpha$. Correspondingly, the clones transfected with PLXSN basic vector were named Ishikawa/vector and HEC-IA/vector.

cDNA transcription and primer sets. Total RNA was extracted using TRIzol reagent (Invitrogen) according to the manufacturer's instructions. The quality and concentrations of RNA samples were assessed by the DNA Counter (Bio-Rad, Munich, Germany). Only samples with an OD260/280 ratio $>1.7$ were used in the experiments. In $20 \mu 1$ of reaction mixture, cDNA was synthesized from $2 \mu \mathrm{g}$ of DNase I-treated total RNA using random hexamer and M-MLV reverse transcriptase (Promega). Transcription was performed as follows: initial denaturation at $95^{\circ} \mathrm{C}$ for $5 \mathrm{~min}$ followed by $95^{\circ} \mathrm{C}$ for $1 \mathrm{~min}$, annealing for $1 \mathrm{~min}$ at $59^{\circ} \mathrm{C}$ for $\mathrm{ERR} \alpha\left(54^{\circ} \mathrm{C}\right.$ for GAPDH) and elongation at $72^{\circ} \mathrm{C}$ for $1 \mathrm{~min}, 35$ cycles and a final extention step at $72^{\circ} \mathrm{C}$ for $10 \mathrm{~min}$. A negative control was set to check for the possibility of exogenous contaminant DNA, and no amplified products were detected under this condition. The PCR products were electrophoresed on $2 \%$ agarose gel with ethidium bromide, and the image intensities were analysed by a gel documentation system. The relative level of ERR $\alpha$ mRNA was semi-quantitated with the ratio of ERR $\alpha$ mRNA and GAPDH mRNA. The special primer set sequences used were as follows: ERR $\alpha$ sense 5'-TGG TCC AGC TCC CAC TCG CT-3'; anti-sense 5'-TGA GAC ACC AGT GCA TTC ACT G-3' (482 bp); ER $\alpha$ sense 5'-CCG CTG GAT TCT TTT TCA AA-3'; anti-sense 5'-AAG GCT CAA ATG CCA AAT TG-3' (151 bp); ERß sense 5'-TGT ATG ACC TGC TGC TGG AG-3'; anti-sense 5'-TCA GCT TGT GAC CTC TGT GG-3' (178 bp); GADPH (as internal control) sense 5'-ACG CAT TTG GTC GTA TTG GG-3'; anti-sense 5'-TGA TTT TGG AGG GAT CTC GC-3' (230 bp).

Western blot analysis. Cell lysates were prepared by mammalian cell lysis/extraction reagent (Sigma). Total soluble proteins were quantified by the Bradford method using a BCA 
protein assay reagent kit (Pierce, USA). Protein (100 $\mu \mathrm{g})$ was loaded and separated on $10 \%$ SDS-polyacrylamide gel electrophoresis and electrophoretically transblotted onto polyvinylidene difluoride membranes. Blotted membranes were pre-blocked with TBS containing $0.1 \%$ Tween-20 and 5\% nonfat dry milk for $2 \mathrm{~h}$, then incubated with an anti-ERR $\alpha$ mouse monoclonal antibody (R\&D, USA) at a dilution of 1:1000 overnight at $4^{\circ} \mathrm{C}$. Subsequently, rabbit polyclonal IgG (Santa Cruz Biotechnology, Santa Cruz, CA, USA) and the ECL detection system (Pierce) were used to visualize the bands. All experiments were repeated three times.

MTT assay. Ishikawa/vector, Ishikawa/ERR $\alpha$, HEC-IA/vector and HEC-IA/ERR $\alpha$ cells were respectively seeded at a density of $1 \times 10^{4}$ cells/well onto 96-well plates and cultured in $90 \%$ RPMI-1640 or DMEM with $10 \%$ FBS for $24 \mathrm{~h}$. This was replaced with phenol red-free medium containing $1 \%$ serum replacement-2, following which cells were cultured for an additional $24 \mathrm{~h}$. Subsequently, $10^{-8} \mathrm{M}$ of $17 \mathrm{~B}-\mathrm{E}_{2}$ or vehicle was added to the cells, which were treated for $24,48,72$ or $96 \mathrm{~h}$. Prior to the assay, the medium was replaced with $20 \mu 1$ of MTT solution $(5 \mathrm{mg} / \mathrm{ml}$ ) per well. After incubation for $4 \mathrm{~h}$, the medium was removed and formazan crystals were dissolved by shaking with $100 \mu \mathrm{l}$ of DMSO for $30 \mathrm{~min}$. Absorbance was measured at $490 \mathrm{~nm}$ with a micro-plate reader (Bio-Rad Inc., Richmond, CA). Six duplicate wells were used for each treatment, and experiments were repeated three times.

Flow cytometry analysis. Ishikawa/vector, Ishikawa/ERR $\alpha$, HEC-IA/vector and HEC/IA-ERR $\alpha$ cells were cultured in phenol red-free medium with $1 \%$ serum replacement- 2 for at least $24 \mathrm{~h}$ and were treated with $10^{-8} \mathrm{M}$ of $17 ß-\mathrm{E}_{2}$ or vehicle for 3 days. Cell cycle distribution was analyzed by flow cytometry. In brief, cells were harvested and washed with phosphatebuffered saline (PBS) twice, and fixed with ice-cold $80 \%$ ethanol overnight at $4^{\circ} \mathrm{C}$. Cells were washed once again and incubated in PBS with ribonuclease A at $37^{\circ} \mathrm{C}$ for $30 \mathrm{~min}$. After a final PBS wash, cells were incubated with propidium iodide $(50 \mu \mathrm{g} / \mathrm{ml})$ for $30 \mathrm{~min}$ at $4^{\circ} \mathrm{C}$ to protect them from light. Then, samples were processed using a FACSort flow cytometer (BD Biosciences) and analyzed using ModFit LT software (BD Biosciences). A minimum of 10,000 cells was counted per sample.

Statistical analysis. The independent samples t-test and ANOVA analysis were used to compare the parametric data with SPSS 10.0 software. A P-value $<0.05$ was considered statistically significant.

\section{Results}

Estrogen represses ERRa expression in ER-positive Ishikawa cells. Endometrial carcinoma Ishikawa cells were determined to be ER-positive and functional. In these cells, the results of semi-quantitative RT-PCR showed that the relative levels of ERR $\alpha$ mRNA were down-regulated after treatment with $10^{-10}$ to $10^{-6} \mathrm{M}$ of $17 \mathrm{~B}-\mathrm{E}_{2}$ for $24 \mathrm{~h}$. The maximally repressed effect ( $\sim 3.6$-fold decrease) was observed at the concentration of $10^{-8} \mathrm{M}$ (Fig. 1A, lane 1-4). Moreover, this down-regulation was largely abrogated by $10^{-6} \mathrm{M}$ of ICI182,780 (Fig. 1A, lane 5).
A
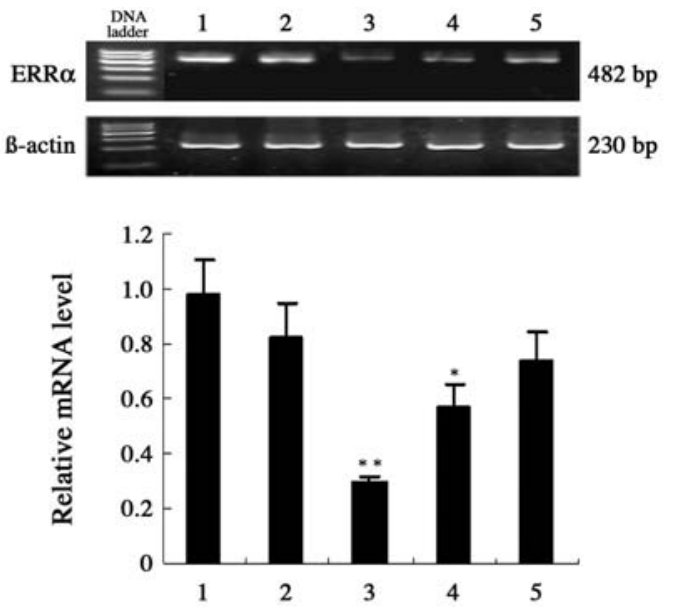

B
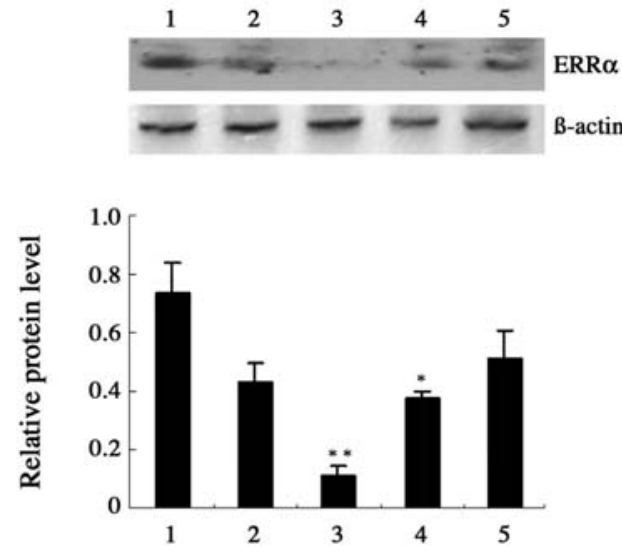

C
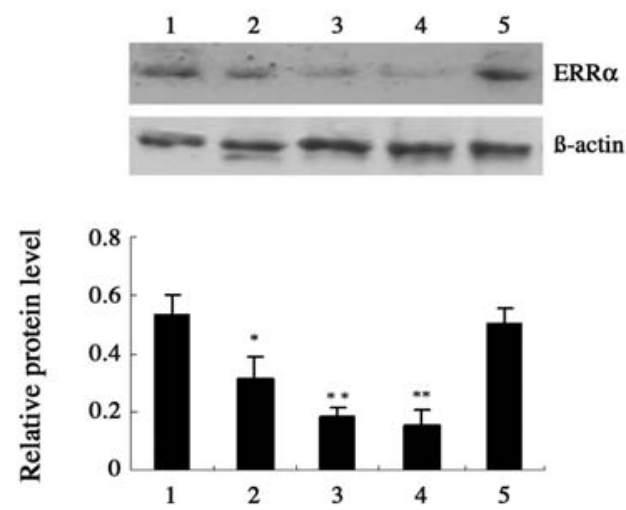

Figure 1. Estrogen down-regulated ERR $\alpha$ expression in Ishikawa cells. Total RNA and proteins were isolated from Ishikawa cells after treatment with different concentrations of $173-\mathrm{E}_{2}$. Semi-quantitative RT-PCR and Western blot analysis were performed as described in Materials and methods. (A) mRNA expression of ERR $\alpha$ after stimulation by $\mathrm{E}_{2}$ and anti-estrogen ICI182,780 for 24 h. (B) Protein expression of ERR $\alpha$ after stimulation by $E_{2}$ and ICI182,780 for $24 \mathrm{~h}$. (C) Protein expression of ERR $\alpha$ after stimulation by $E_{2}$ and ICI182,780 for $48 \mathrm{~h}$. Lane 1, control; 2, $10^{-10} \mathrm{M} \mathrm{E}_{2} ; 3,10^{-8} \mathrm{M} \mathrm{E}_{2} ; 4,10^{-6} \mathrm{M} \mathrm{E}_{2}$; $5,10^{-8} \mathrm{M} \mathrm{E}_{2}$ plus $10^{-6} \mathrm{M}$ ICI182,780. Each bar represents the mean $\pm \mathrm{SD}$ of three independent experiments ( ${ }^{*} \mathrm{p}<0.05 \mathrm{vs}$. control; ${ }^{* *} \mathrm{p}<0.01 \mathrm{vs}$. control).

We also observed similar changes in protein levels by Western blot analysis. An 6.6-fold decrease in ERR $\alpha$ protein was observed at the concentration of $10^{-8} \mathrm{M}$ of $17 \beta-\mathrm{E}_{2}$, and a 2.0-fold decrease at the concentration of $10^{-6} \mathrm{M}$ (Fig. 1B) after 
A
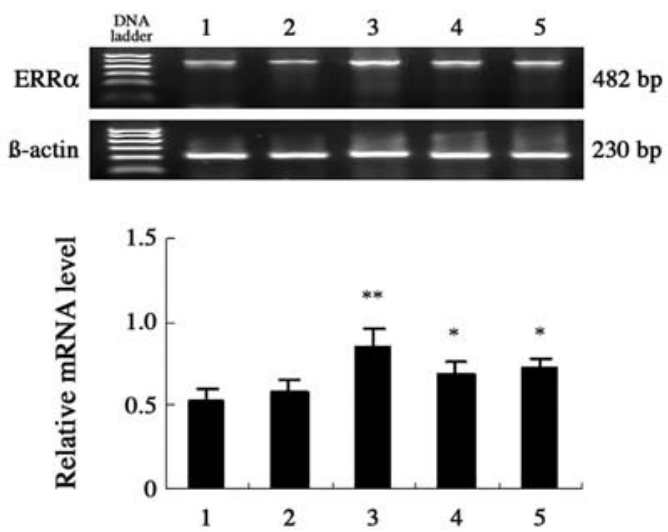

B
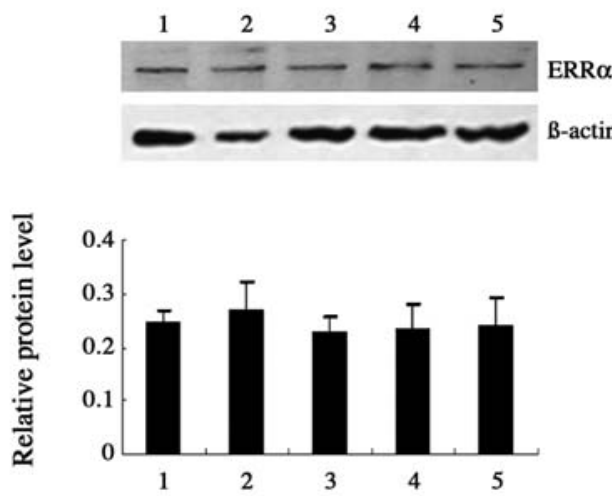

C
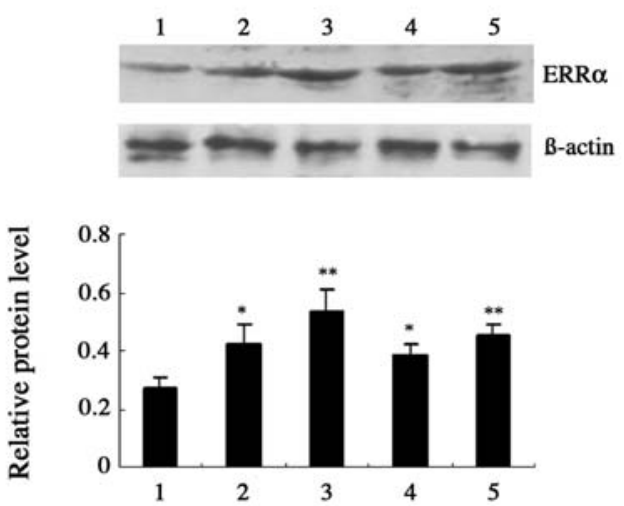

Figure 2. Estrogen up-regulated ERR $\alpha$ expression in HEC-IA cells. Total RNA and proteins were isolated from HEC-IA cells after treatment with different concentrations of $17 \mathrm{~B}-\mathrm{E}_{2}$. Semi-quantitative RT-PCR and Western blot analysis were performed as described in Materials and methods. (A) mRNA expression of ERR $\alpha$ after stimulation by $\mathrm{E}_{2}$ and anti-estrogen ICI182,780 for 24 h. (B) Protein expression of ERR $\alpha$ after stimulation by $E_{2}$ and ICI182,780 for $24 \mathrm{~h}$. (C) Protein expression of ERR $\alpha$ after stimulation by $\mathrm{E}_{2}$ and ICI182,780 for $48 \mathrm{~h}$. Lane 1, control; 2, $10^{-10} \mathrm{M} \mathrm{E}_{2} ; 3,10^{-8} \mathrm{M} \mathrm{E}_{2} ; 4,10^{-6} \mathrm{M} \mathrm{E}_{2}$; $5,10^{-8} \mathrm{M} \mathrm{E}_{2}$ plus $10^{-6} \mathrm{M}$ ICI182,780. Each bar represents the mean $\pm \mathrm{SD}$ of three independent experiments ( ${ }^{*} \mathrm{p}<0.05 \mathrm{vs}$. control; ${ }^{* *} \mathrm{p}<0.01 \mathrm{vs}$. control).

treatment for $24 \mathrm{~h}$. After treatment for $48 \mathrm{~h}, 3.0$ - and 3.5-fold decreases of ERR $\alpha$ protein were observed at the concentrations of $10^{-6}$ and $10^{-8} \mathrm{M}$ of $17 \beta-\mathrm{E}_{2}$ (Fig. 1C).

Estrogen stimulates ERR expression in ER-negative HEC-IA cells. HEC-IA cells were determined to be ER-negative and non-functional. The opposite phenomena to that seen in

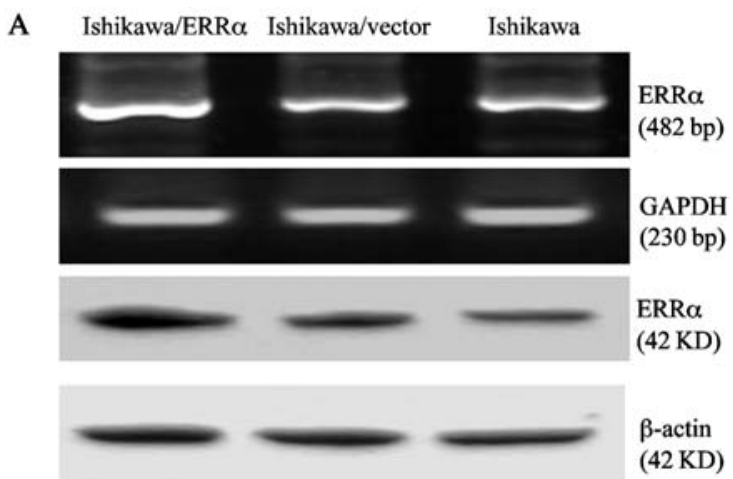

B

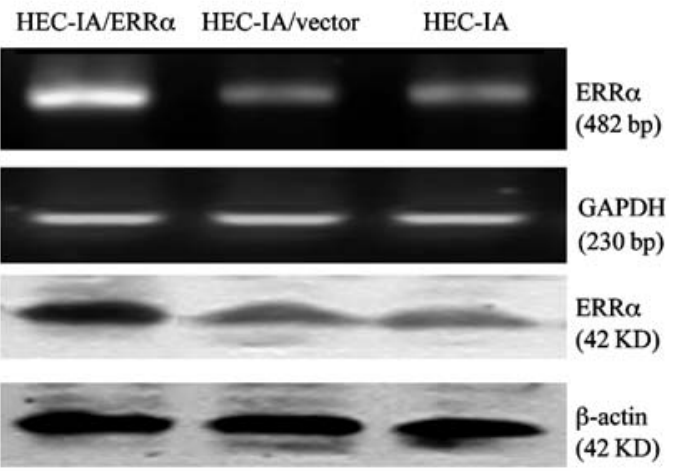

Figure 3. Identification of cell lines with $\operatorname{ERR} \alpha$ overexpression. Ishikawa and HEC-IA cells were transfected with $1 \mu \mathrm{g}$ of the PLXSN-ERR $\alpha$ expression vector or basic vector, respectively. G418 selection was carried out for 2 weeks. Resistant single clones were expanded with medium containing $300 \mu \mathrm{g} / \mathrm{ml} \mathrm{G} 418$. The clones with the highest expression of ERR $\alpha$ are shown. (A) The Ishikawa cell clone with the highest expression of ERR $\alpha$. (B) The HEC-IA cell clone with the highest expression of ERR $\alpha$.

Ishikawa cells was observed in these cells. After treatment with different concentrations of $17 ß-\mathrm{E}_{2}$ for $24 \mathrm{~h}$, mRNA expression of ERR $\alpha$ was extensively up-regulated. The maximal effect was found at the concentration of $10^{-8} \mathrm{M}$. Moreover, this up-regulation was not abrogated by ICI182,780 $\left(10^{-6} \mathrm{M}\right)$ (Fig. 2A). However, the results of Western blot analysis showed lagged protein changes. After treatment with $17 ß-\mathrm{E}_{2}$ for $48 \mathrm{~h}$, ERR $\alpha$ proteins were obviously increased compared with the control (Fig. 2C), but no significant changes were exhibited at $24 \mathrm{~h}$ after treatment with $17 \mathrm{~B}-\mathrm{E}_{2}$ (Fig. 2B).

Identification of ERRa overexpression in constructed cells. These experiments have revealed that, though $173-\mathrm{E}_{2}$ might modulate ERR $\alpha$ expression, it has the adverse effect in ERpositive and -negative endometrial carcinoma cells. To further clarify the biological roles of ERR $\alpha$ in ER $\alpha$-positive and -negative endometrial carcinomas, we selected three clones of Ishikawa and HEC-IA cells with ERR $\alpha$ overexpression for further testing. The results of semi-quantitative RT-PCR and Western blotting indicated that the expression of ERR $\alpha$ mRNA and protein in the Ishikawa/ERR $\alpha$ and HEC-IA/ERR $\alpha$ cells was significantly higher than in untransfected cells and cells transfected with empty vector (Fig. 3), increasing 3.6-fold in Ishikawa cells and 5.2-fold in HEC-IA cells compared with the controls. These two endometrial carcinoma cell lines 


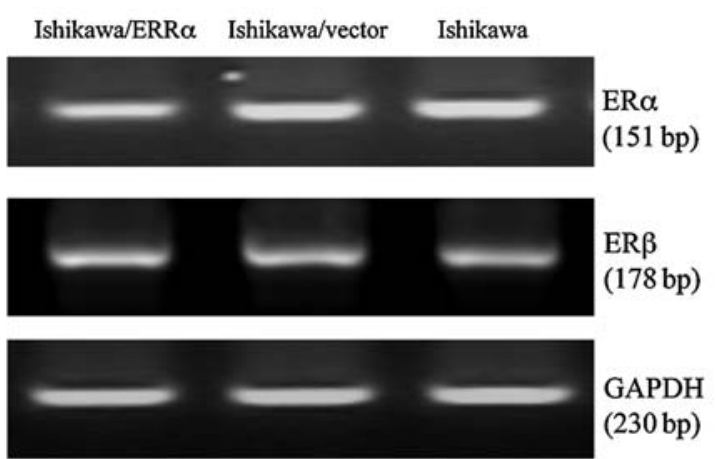

Figure 4. Semi-quantitative RT-PCR analysis of ER $\alpha$ and ERß expression in Ishikawa/ERR $\alpha$ cells. Relative levels of ER $\alpha$ and ERß mRNA were normalized with GAPDH. (a) The relative level of ER $\alpha$ mRNA was reduced in Ishikawa/ERR $\alpha$ cells compared with transfected cells with basic vector or untransfected cells. (b) No change was noted in ERß mRNA expression among various cells. Each bar represents the mean \pm SD of three independent experiments. a

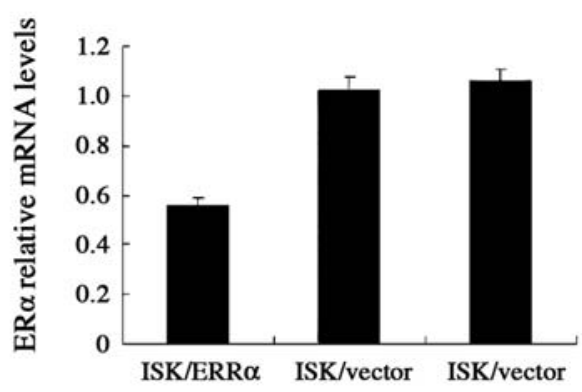

b

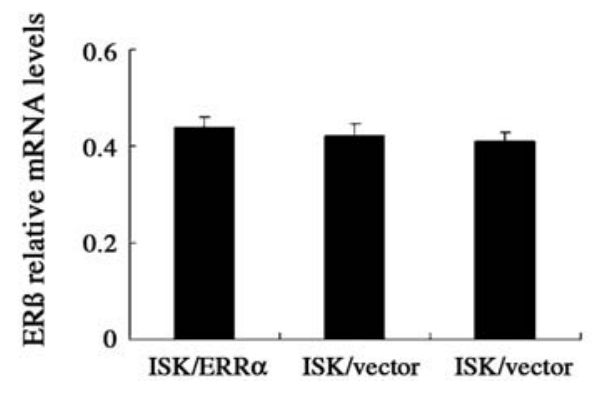

with stable overexpression of ERR $\alpha$, which we successfully constructed for the first time, provide good models for further research on the biological function of ERR $\alpha$ in endometrial carcinoma.

Effect of ERR a overexpression on ER $\alpha$ and ERß $m R N A$ expression. To determine whether functional crosstalk between ERR $\alpha$ and ERs is possible, we next examined the expression of $\mathrm{ER} \alpha$ and ERß mRNA in Ishikawa/ERR $\alpha$, Ishikawa/vector and normal Ishikawa cells. The results showed that overexpression of ERR $\alpha$ reduced the transcriptional level of ER $\alpha$ but not ERß in Ishikawa cells (Fig. 4).

Effect of ERRa overexpression on cell proliferation and the cell cycle. To ascertain whether the overexpression of ERR $\alpha$ alters cellular biological behavior, we analyzed cell proliferation and cell cycle distribution in Ishikawa and HEC-IA cells by MTT assay and flow cytometry. There were no significant differences in growth rate and cell cycle distribution between Ishikawa/ERR $\alpha$ and Ishikawa/vector cells in the absence of $17 ß-\mathrm{E}_{2}$ (Fig. 5 and Table I). However, at 3 days post-treatment with $17 \beta-E_{2}$, the growth rate of Ishikawa/ERR $\alpha$ cells was markedly inhibited compared to that of Ishikawa/vector cells. Moreover, the percentage of cells in the $G_{0}-G_{1}$ phase in Ishikawa/ERR $\alpha$ cells was significantly higher than in the Ishikawa/vector cells, and was accompanied by a decrease in $\mathrm{S}$ phase cells. However, the opposite results were observed in HEC-IA cells. The growth rate of HEC-IA/ERR $\alpha$ cells was obviously faster than that of the control cells in the presence or absence of $17 ß-E_{2}$ (Fig. 5). A marked increase in $S$ phase cells and a decrease in $\mathrm{G}_{0}-\mathrm{G}_{1}$ phase cells in HEC-IA/ERR $\alpha$ cells were also observed as compared to the control cells (Table I). These findings suggest that the overexpression of ERR $\alpha$ might have a differential impact on cell growth and cell cycle distribution in ER-positive and -negative endometrial carcinomas.

\section{Discussion}

The action induced by estrogen involves a complicated process that involves not only ERs, target genes and cofactors, but also the closely related orphan nuclear receptors ERRs. Physiological ligands for ERRs have not yet been found, and some researches have demonstrated that they can constitutively interact with co-activators independently of any natural estrogen. However, ERR $\alpha$ can interfere with the estrogen-ER signaling pathway by competing with ER $\alpha$ for the same target gene sites and coregulators (13-16,30). In addition, ER $\alpha$ and $\mathrm{ERR} \alpha$ co-expression has been reported in some estrogenresponsive tissues, such as that of the breast, ovary, uterus and bone (23-25,31-33). ERR $\alpha$ may therefore participate in the tumorigenesis of estrogen-related tumors.

To better understand the role of ERR $\alpha$ in estrogenresponsive tissues and endometrial carcinoma, we examined its estrogenic responsiveness and its functional relationship with $\mathrm{ER} \alpha$ in ER-positive and -negative endometrial carcinoma cells, demonstrating its adverse effects on these cells. In ER-positive Ishikawa cells, the expression of ERR $\alpha$ was down-regulated by $17 \beta-E_{2}$, an effect partially abrogated by the pure antiestrogen drug ICI182,780. These findings imply that $173-\mathrm{E}_{2}$ may indirectly modulate the expression of ERR $\alpha$ via estrogenER signaling pathways. On the other hand, in ER-negative HEC-IA cells the expression of ERR $\alpha$ was up-regulated by $17 ß-\mathrm{E}_{2}$, an effect which could not be abrogated by ICI182,780.

It has been suggested that $17 ß-\mathrm{E}_{2}$ might regulate the expression of ERR $\alpha$ in HEC-IA cells, although via non-ER pathways. Liu et al (32) confirmed that the ERR $\alpha$ gene was a downstream target of $\mathrm{ER} \alpha$; multiple steroid hormone response element half-sites present in the ERR $\alpha$ promoter might be responsible for this estrogen-responsive activation. Therefore, in ER-positive cells, ER $\alpha$ might be a direct transcriptional repressor of $E R R \alpha$, and could inhibit its expression. However, in ER-negative cells, the mechanism by which $17 ß-\mathrm{E}_{2}$ 
A

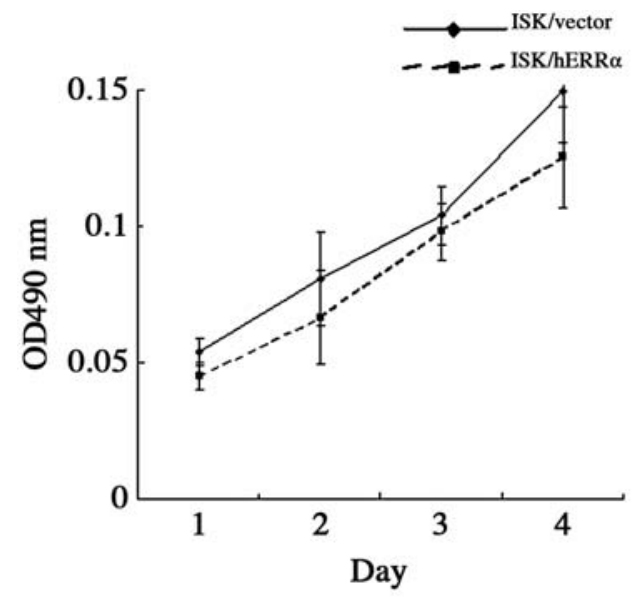

B

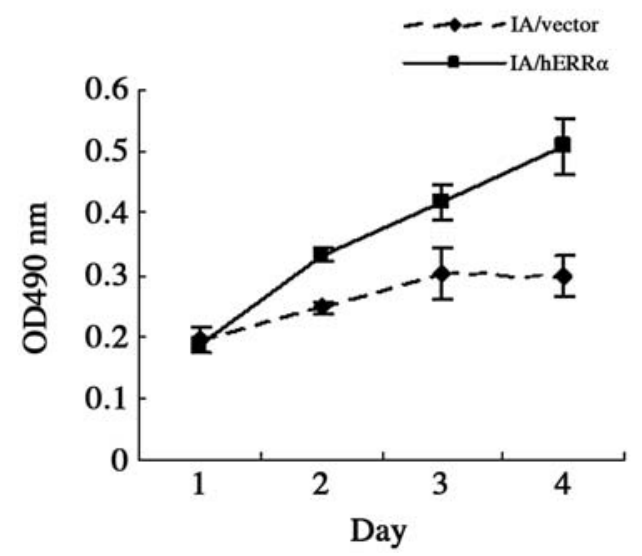

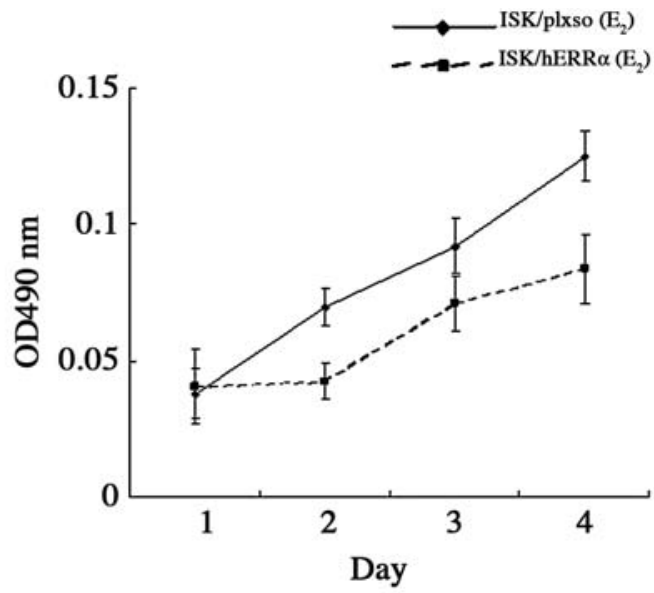

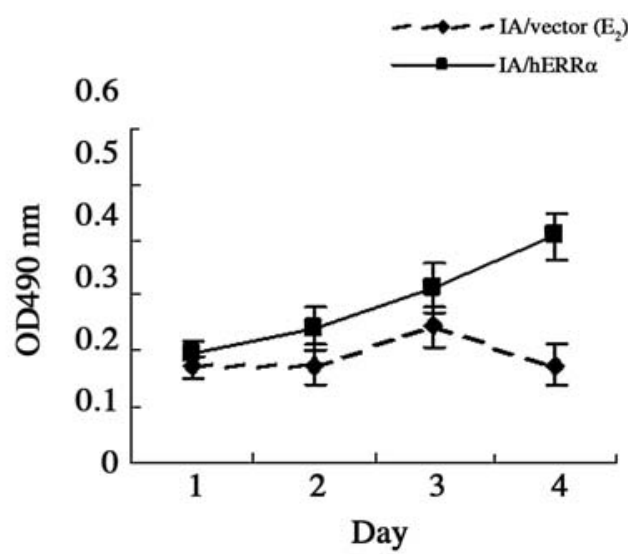

Figure 5. Effect of ERR $\alpha$ overexpression on cell proliferation. Cell proliferation was analyzed by the MTT assay. Ishikawa/vector, Ishikawa/ERR $\alpha$, HEC-IA/vector and HEC-IA/ERR $\alpha$ cells were respectively seeded at a density of 1x10 4 cells/well onto 96-well plates. Ishikawa (A) and HEC-IA cells (B) were treated with vehicle or $10^{-8} \mathrm{M}$ of $\mathrm{E}_{2}$ for $24,48,72$ and $96 \mathrm{~h}$ as described in Materials and methods. Absorbance was measured at $490 \mathrm{~nm}$. Six wells were used for each treatment. Each point represents the mean $\pm \mathrm{SD}$ of three independent experiments.

Table I. Cell cycle distribution of post-transfected Ishikawa and HEC-IA cells.

\begin{tabular}{|c|c|c|c|c|c|c|}
\hline & $\mathrm{G}_{0}(\%)$ & P-value & $\mathrm{G}_{2}-\mathrm{M}(\%)$ & P-value & $\mathrm{S}(\%)$ & P-value \\
\hline ISK/vector ( $\mathrm{E}_{2}$-free $)$ & $55.8000 \pm 6.3074$ & 0.602 & $4.8850 \pm 6.7104$ & 0.834 & $39.3150 \pm 0.4031$ & 0.561 \\
\hline ISK/ERR $\alpha\left(E_{2}\right.$-free $)$ & $59.0100 \pm 1.1314$ & & $3.5150 \pm 4.2921$ & & $37.4750 \pm 3.1608$ & \\
\hline ISK/vector $\left(\mathrm{E}_{2}\right)$ & $43.2650 \pm 1.5768$ & 0.010 & $9.3100 \pm 4.7659$ & 0.347 & $42.4250 \pm 0.7283$ & 0.018 \\
\hline $\operatorname{ISK} / \mathrm{ERR} \alpha\left(\mathrm{E}_{2}\right)$ & $58.5650 \pm 1.3930$ & & $4.1600 \pm 1.9940$ & & $37.2750 \pm 0.6010$ & \\
\hline HEC-IA/vector ( $E_{2}$-free $)$ & $51.6750 \pm 1.5203$ & 0.035 & $16.5850 \pm 0.4596$ & 0.963 & $31.7400 \pm 1.0607$ & 0.014 \\
\hline HEC-IA/ERR $\alpha\left(\mathrm{E}_{2}\right.$-free $)$ & $41.6050 \pm 2.0153$ & & $16.4750 \pm 2.6658$ & & $41.9200 \pm 0.6505$ & \\
\hline HEC-IA/vector $\left(\mathrm{E}_{2}\right)$ & $52.3233 \pm 2.6364$ & 0.014 & $11.3933 \pm 1.4561$ & 0.059 & $36.2833 \pm 1.6257$ & 0.001 \\
\hline HEC-IA/ERR $\alpha\left(\mathrm{E}_{2}\right)$ & $43.5033 \pm 2.5727$ & & $5.0500 \pm 3.9262$ & & $51.4467 \pm 2.4800$ & \\
\hline
\end{tabular}

Ishikawa and HEC-IA cells with overexpression of ERR $\alpha$ were cultured in the presence or absence of 17ß-E $\mathrm{E}_{2}$ for 3 days, and cell cycle distribution was measured. The numbers represent the mean $\pm \mathrm{SD}$ of three independent experiments.

regulates the expression of ERR $\alpha$ remains unclear. A previous study demonstrated that ERR $\alpha$ competed with ER $\alpha$ in binding to the ERE and repressed ERE-dependent transactivation in ER-positive MCF-7 cells, whereas in ER-negative HeLa cells it activated transcription (34). In light of these findings, we speculate that ERR $\alpha$ may play completely different roles in ER-positive and -negative endometrial carcinomas.

To further elucidate the roles and the molecular mechanism of ERR $\alpha$ in endometrial carcinogenesis, we constructed cell lines with an overexpression of ERR $\alpha$ by stable transfection. 
The biological behaviors of these two cell lines were analyzed by MTT assay and flow cytometry. The results confirm that ERR $\alpha$ plays a distinct role in ER-positive and -negative endometrial carcinomas. Through stable transfection and the MTT assay, we found that overexpression of ERR $\alpha$ inhibited cell growth in the presence of $17 ß-\mathrm{E}_{2}$ in ER-positive and functional Ishikawa cells. This inhibitory effect seemed to be due to a $\mathrm{G}_{0}-\mathrm{G}_{1}$ cell cycle arrest rather than induced apoptosis (data not shown). In contrast, the overexpression of ERR $\alpha$ stimulated cell proliferation in ER-negative HEC-IA cells independently of $17 ß-\mathrm{E}_{2}$. This accelerated cell growth was also found to be associated with changes in cell cycle distribution. These findings further confirm that ERR $\alpha$ plays an entirely different role in ER-positive and -negative endometrial carcinoma. In ER-positive cells, it acts as the repressor of ER $\alpha$ and competes to bind estrogen responsive genes. However, in ER-negative cells, it becomes the activator and constitutively activates the transcription of ERE-containing genes.

Previous studies have revealed extensive crosstalk between $\mathrm{ERR} \alpha$ and $\mathrm{ER} \alpha(18,21,30)$, and our stable transfection experiments confirm this complex interaction. The overexpression of ERR $\alpha$ repressed the transcription of ER $\alpha$ but not ERß in Ishikawa cells. The mechanism of this negative regulation is at present unclear.

Based on the current study, we can hypothesize that the preponderant expression of $\mathrm{ER} \alpha / \mathrm{ERR} \alpha$ in cells might be the key to endometrial carcinogenesis. Induced by estrogen or agonist, the E-ER complex might directly or indirectly inhibit the expression of ERR $\alpha$ in both mRNA transcription and protein translation in ER-positive and functional cells, resulting in the competitive inhibition of $\mathrm{ERR} \alpha$ on $\mathrm{ER} \alpha$ being extensively reduced, and in the estrogenic effect being indirectly magnified. This might partially explain why longterm estrogen stimulation induces hyperplasia and tumorigenesis of the endometrium $(35,36)$. On the other hand, in ERnegative cells, estrogen up-regulated the expression of ERR $\alpha$. Moreover, ERR $\alpha$ could constitutively transactivate estrogen responsive genes independently of the ER $\alpha$ function, leading to estrogenic effects $(16,17,37,38)$.

In our previous study, we found increased expression of $\mathrm{ERR} \alpha$ in $\mathrm{ER} \alpha$-negative compared to ER $\alpha$-positive endometrial cancer tissues (29). Therefore, we proposed that the classic E-ER signaling pathway might be a key factor leading to hormone-dependent endometrial carcinoma. However, in hormone-independent endometrial carcinoma, the ERR $\alpha$ mediated pathway may play a vital role. The change in the relative amount of $\mathrm{ER} \alpha / \mathrm{ERR} \alpha$ and the functional conversion of ERR $\alpha$ from a repressor to an activator might be crucial steps in the development of endometrial carcinoma from the hormone-dependent to the hormone-independent type. The detailed mechanism by which this occurs remains to be further elucidated.

Results from this study suggest that ERR $\alpha$, a ligandundefined nuclear receptor, may be the next target of endocrine therapy in endometrial carcinoma. It is possible that an ERR $\alpha$-specific inhibitor or therapeutically synthetic ligands will be valuable in the treatment of estrogen-independent endometrial carcinoma. Moreover, future endocrine therapeutic strategies for treating estrogen-related cancers should involve not only $\mathrm{ER} \alpha$, but ERR $\alpha$ as well.

\section{Acknowledgements}

We thank Professor J.M. Vanacker for generously providing the plasmids. We also thank Drs C. Denkert, A. Mustea and D. Kösgen for their great support in this work. This research was supported by the National Nature Science Foundation of China (NSFC, serial no. 30371477).

\section{References}

1. Jemal A, Thomas A and Murray T: Cancer statistics. CA Cancer J Clin 52: 23-47, 2002.

2. Jemal A, Murray T, Samules A, Ghafoor A, Ward E and Thun MJ: Cancer statistics. CA Cancer J Clin 53: 5-26, 2003.

3. Lax SF: Molecular genetic pathways in various types of endometrial carcinoma: from a phenotypical to a molecular-based classification. Virchows Arch 444: 213-223, 2004.

4. Kuiper GG, Enmark E, Pelto-Huikko M, Nilsson S and Gustafsson JA: Cloning of a novel receptor expressed in rat prostate and ovary. Proc Natl Acad Sci USA 93: 5925-5930, 1996.

5. Rosenfeld MG and Glass CK: Coregulator codes of transcriptional regulation by nuclear receptors. J Biol Chem 276: 36865-36868, 2001.

6. Giguère $\mathrm{V}$, Tremblay $\mathrm{A}$ and Tremblay GB: Estrogen receptor $B$ : re-evaluation of estrogen and antiestrogen signaling. Steroids 63: 335-339, 1998.

7. Cowley SM, Hoare S, Mosselman S and Parker MG: Estrogen receptors $\alpha$ and $\beta$ form heterodimers on DNA. J Biol Chem 272: 19858-19862, 1997.

8. Pettersson K, Grandien K, Kuiper GGJM and Gustafsson JA: Mouse estrogen receptor $\beta$ forms estrogen response elementbinding heterodimers with estrogen receptor $\alpha$. Mol Endocrinol 11: 1486-1496, 1997.

9. Giguère V, Yang N, Segui $P$ and Evans RM: Identification of a new class of steroid hormone receptors. Nature 331: 91-94, 1988.

10. Hong H, Yang L and Stallcup MR: Hormone-independent transcriptional activation and coactivator binding by novel orphan nuclear receptor ERR3. J Biol Chem 274: 22618-22626, 1999.

11. Heard DJ, Norby PL, Holloway J and Vissing H: Human ERR $\gamma$, a third member of the estrogen receptor-related receptor (ERR) subfamily of orphan nuclear receptors: tissue-specific isoforms are expressed during development and in the adult. Mol Endocrinol 14: 382-392, 2000.

12. Horard B and Vanacker JM: Estrogen receptor-related receptors: orphan receptors desperately seeking a ligand. J Mol Endocrinol 31: 349-357, 2003.

13. Johnston SD, Liu X, Zuo F, Eisenbraun TL, Wiley SR, Kraus RJ and Mertz JE: Estrogen-related receptor- $\alpha 1$ functionally binds as a monomer to extended half-site sequences including ones contained within estrogen-response elements. Mol Endocrinol 11: 342-352, 1997.

14. Yang N, Shigeta H, Shi H and Teng CT: Estrogen-related receptor, hERR1, modulates estrogen receptor-mediated response of human lactoferrin gene promoter. J Biol Chem 271: 5795-5804, 1996.

15. Sladek R, Bader JA and Giguère V: The orphan nuclear receptor estrogen-related receptor $\alpha$ is a transcriptional regulator of the human medium-chain acyl coenzyme A dehydrogenase gene. Mol Cell Biol 17: 5400-5409, 1997.

16. Xie W, Hong H, Yang NN, Lin RJ, Simon CM, Stallcup MR and Evans RM: Constitutive activation of transcription and binding of coactivator by estrogen-related receptors 1 and 2. Mol Endocrinol 13: 2151-2162, 1999.

17. Chen S, Zhou D, Yang C and Sherman M: Molecular basis for the constitutive activity of estrogen related receptor $\alpha-1$. J Biol Chem 276: 28465-28470, 2001.

18. Zhang $Z$ and Teng TC: Estrogen receptor $\alpha$ and estrogen receptorrelated receptor $\alpha 1$ compete for binding and coactivator. Mol Cell Endocrinol 172: 223-233, 2001.

19. Zhang $Z$ and Teng CT: Estrogen receptor-related receptor $\alpha 1$ interacts with coactivator and constitutively activates the estrogen response elements of the human lactoferrin gene. J Biol Chem 275: 20837-20846, 2000.

20. Kamei Y, Ohizumi H, Fujitani Y, Nemoto T, Tanaka T, Takahashi N, Kawada T, Miyoshi M, Ezaki O and Kakizuka A: PPAR $\gamma$ coactivator $13 / E R R$ ligand 1 is an ERR protein ligand, whose expression induces a high-energy expenditure and antagonizes obesity. Proc Natl Acad Sci USA 100: 12378-12383, 2003. 
21. Vanacker JM, Pettersson K, Gustafsson J and Laudet V: Transcriptional targets shared by estrogen receptor-related receptors (ERRs) and estrogen receptor (ER) $\alpha$ but not by ER $\beta$. EMBO J 18: 4270-4279, 1999.

22. Yang C, Zhou D and Chen S: Modulation of aromatase expression in the breast tissue by ERR alpha-1 orphan receptor. Cancer Res 58: 5695-5700, 1998.

23. Ariazi EA, Clark GM and Mertz JE: Estrogen-related receptor alpha and estrogen-related receptor gamma associate with unfavorable and favorable biomarkers, respectively, in human breast cancer. Cancer Res 62: 6510-6518, 2002.

24. Suzuki T, Miki Y, Moriya T, Shimada N, Ishida T, Hirakawa H, Ohuchi $\mathrm{N}$ and Sasano H: Estrogen-related receptor in human breast carcinoma as a potent prognostic factor. Cancer Res 64: 4670-4676, 2004.

25. Sun P, Sehouli J, Denkert C, Mustea A, Konsgen D, Koch I, Wei L and Lichtenegger W: Expression of estrogen receptorrelated receptors, a subfamily of orphan nuclear receptors, as new tumor biomarkers in ovarian cancer cells. J Mol Med 83: 457-467, 2005.

26. Cheung CP, Yu S, Wong KB, Chan LW, Lai FMM, Wang X, Suetsugi M, Chen S and Chan FL: Expression and functional study of estrogen receptor-related receptors in human prostatic cells and tissues. J Clin Endocrinol Metab 90: 1830-1844, 2005.

27. Cavallini A, Notarnicola M, Giannini R, Montemurro S, Lorusso D, Visconti A, Minervini F and Caruso MG: Oestrogen receptor-related receptor alpha $(\mathrm{ERR} \alpha)$ and oestrogen receptors (ER $\alpha$ and $E R \beta)$ exhibit different gene expression in human colorectal tumor progression. Eur J Cancer 41: 1487-1494, 2005.

28. Watanabe A, Kinoshita Y, Hosokawa K, Mori T, Yamaguchi T and Honjo H: Function of estrogen-related receptor alpha in human endometrial cancer. J Clin Endocrinol Metab 91: 1573-1577, 2006.
29. Gao M, Sun P, Wang J, Zhao D and Wei L: Expression of estrogen receptor-related receptor isoforms and clinical significance in endometrial adenocarcinoma. Int J Gynecol Cancer 16: 827-833, 2006.

30. Giguère V: To ERR in the estrogen pathway. Trends Endocrinol Metab 13: 220-225, 2002.

31. Horard B, Rayet B, Triqueneaux G, Laudet V, Delaunay F and Vanacker JM: Expression of the orphan nuclear receptor ERRalpha is under circadian regulation in estrogen-responsive tissues. J Mol Endocrinol 33: 87-97, 2004.

32. Liu D, Zhang Z, Gladwell W and Teng CT: Estrogen stimulates estrogen-related receptor alpha gene expression through conserved hormone response elements. Endocrinology 144: 4894-4904, 2003.

33. Bonnelye E, Vanacker JM, Dittmar T, Begue A, Desbiens X, Denhardt DT, Aubin JE, Laudet V and Fournier B: The ERR-1 orphan receptor is a transcriptional activator expressed during bone development. Mol Endocrinol 11: 905-916, 1997.

34. Kraus RJ, Ariazi EA, Farrell ML and Mertz JE: Estrogen-related receptor $\alpha 1$ actively antagonizes estrogen receptor-regulated transcription in MCF-7 mammary cells. J Biol Chem 277: 24826-24834, 2002.

35. Yager JD and Liehr JG: Molecular mechanisms of estrogen carcinogenesis. Annu Rev Pharmacol Toxicol 266: 203-232, 1996.

36. Henderson BE and Feigelson HS: Hormonal carcinogenesis. Carcinogenesis 21: 427-433, 2000.

37. Vanacker JM, Bonnelye E, Chopin-Delannoy S, Delmarre C, Cavailles V and Laudet V: Transcriptional activities of the orphan nuclear receptor ERR alpha (estrogen receptor-related receptoralpha). Mol Endocrinol 13: 764-773, 1999.

38. Lu D, Kiriyama Y, Lee KY and Giguere V: Transcriptional regulation of the estrogen-inducible pS2 breast cancer marker gene by the ERR family of orphan nuclear receptors. Cancer Res 61: 6755-6761, 2001. 